\title{
Determinants of Capital Adequacy Ratio of Commercial Banks in Nepal
}

\author{
Bishnu Prasad Bhattarai, PhD \\ Academic Director / Business Unit Head, Excel Business College \\ Pokhara University Affiliated, New Baneshwor, Kathmandu \& Faculty Member \\ Patan Multiple Campus, Tribhuvan University, Patan Dhoka, Lalitpur, Nepal \\ E-mail: drbhattarai2019@gmail.com / bishnu.bhattarai@excelcollege.edu.np / \\ bishnu.bhattarai@pmc.tu.edu.np
}

Received: March 1, 2020 Accepted: May 2, $2020 \quad$ Published: June 1, 2020

doi:10.5296/ajfa.v12i1.17521ＵRL: https://doi.org/10.5296/ajfa.v12i1.17521

\begin{abstract}
The study attempts to determine the capital adequacy ratio of commercial banks in Nepal. This study is based on the secondary balance panel data. The data were collected from the 11 commercial banks for the period of 2013/14 to 2017/18 leading to 55 observations. The convenience sampling technique has been used to selection of sample of the study. The study period has been made for fresh data in the analysis. The descriptive, correlational and casual comparative research design has been used for data analysis. The study assumes that the capital adequacy ratio of commercial banks depends on bank specific variable: credit risk, asset quality, management quality, return on assets, liquidity, size of bank and macroeconomics variables gross domestic products growth rate and consumer price index i.e. inflation rate. The three different model like Pooled OLS, Fixed Effects Model and Random Effects Model have been used for data analysis. The results of the study revealed that the liquidity has positive and statistically significant effects on capital adequacy ratio. Size of bank and inflation rate have negatively and statistically significant results. The others variables profitability, asset quality, credit risk, management quality and growth of gross domestic products does not effect to capital adequacy ratio. The study concluded that liquidity, size of bank and inflation have major determinants of capital adequacy ratio in Nepal.
\end{abstract}

Keywords: Commercial bank, Capital adequacy ratio, credit risk, asset quality, management quality, return on assets, liquidity, size of bank, gross domestic products growth rate, inflation rate 


\section{Introduction}

Capital adequacy rules are safety valve for regulators and banks' clients/shareholders to reduce expected risks faced by commercial banks especially for cross border transactions as these rules are applied compulsory by all banks internationally. Applying these rules will achieve rational management and governance (El-Ansary \& Hafez; 2015).

Capital adequacy ratio (CAR) is an important indicator of bank safety sustainability. Banks that can guarantee CAR means the bank has the power to resist the financial crisis, protecting the bank itself and funds from depositors (Usman, Lestari \& Puspa; 2019)

CAR is one of the major indicators of the stability of the commercial banks. Pertinent to its pervasive importance, over the years, the regulators and policymakers focused on the maintenance of the particular level of capital ratio (CR) to minimize the solvency and liquidation risk. It is an important measure of "safety and soundness" for banks and depository institutions because it serves as a buffer or cushion for absorbing losses. It is one of the major benchmarks for financial institutions the world over, especially with the introduction and adoption of the various Basel Accords. Due to a poor capital standard some depository institutions (DIs) failed recently. Therefore, stakeholders such as regulators, managers, researchers, etc. are concerned to fix a precise level of long-term sources of fund in their capital structure. DIs are highly levered firm because major portion of their capital structure consists of debt collected from deposits. One of essential requirements for banks and financial institutions is adequate and sufficient capital and every banks and financial organizations must keep balance between capital and available risk in its assets in order to guarantee its stability. Thus it has become one of the most important criteria for depository institutions.

CAR is decided by central banks and bank regulators to prevent commercial banks from taking excess leverage and becoming insolvent in the process. It is an acknowledged economic fact that banks cannot underestimate the role of Capital adequacy since adequacy of capital in banks directly influences the amount of funds available for loans disbursement which invariably affects their risk appetite, efficiency and stability.

In Nepalese context, Nepal Rastra Bank (NRB) issued some considerations for commercial banks in order to create healthy banking system and have ability to compete with worldwide should be preparing Minimum Capital Adequacy Ratio that meets with the international standards. Capital Adequacy ratio means amount of capital to ensure that banks can handle risk exposures. Implementing the Minimum Capital Adequacy Ratio must be adjusted to risk profile for absorb the potential losses on risk exposure as well as to fulfilling the minimum capital requirement. The Basel III norms stipulated a capital to risk weighted assets of $8 \%$. However, as per NRB norms, Nepal scheduled commercial banks are required to maintain a CAR of $11 \%$.

Hence, the survival of Banks is vested with the maintenance of sufficient capital and it serves as buffer in the event of liquidity crunch. In this regards, the main research question of this study as follows: What are the determinants of capital adequacy ratio of commercial banks in Nepal? 
Although, review of literature in Nepalese context very limited research have been found. These study were: Shrestha, Raut, Yadhav and Thapaliya (2014), Poudel and Khanal (2015), Aryal (2016) and Adhikari (2017). In the changing situations this study has fulfill the new knowledge gap and recent literature in this phenomena.

The purpose of this study is to determine the capital adequacy ratio of commercial banks in Nepal. The remainder of the study organized as follows: Section two describes the literature review. Section three explain the research methodology, section four focuses on empirical results and final section draws the summary and conclusion of the study.

\section{Literature Review}

The study were conducted in many countries in around world to determine capital adequacy ratio of commercial banks or others financial institutions. The some valuable literature has been reviewed as follows.

Shrieves and Dahl (1992) have investigated the relationship between changes in risk and capital in a large sample of banks. A positive association between changes in risk and capital is found. The fact that this finding holds in banks with capital ratios in excess of regulatory minimum levels supports the conclusion that, for most banks, bank owners' and/or managers' private incentives work to limit total risk exposure. Results for banks which were undercapitalized by regulatory standards indicate that regulation was at least partially effective during the period covered. Overall, the findings support a conclusion that changes in bank capital over the period studied have been 'risk-based'.

Białas and Sole (2010) have studied on the capital adequacy ratio (CAR) determinants of a bank's core capital to the assets and off-balance liabilities weighted by the risk. The core capital of the bank is supposed to absorb the potential losses due to the risk of the banking activities. It has been specified that the value of this coefficient cannot be lower than $8 \%$. Throughout the years the way of calculating the ratio has been changing, which is the subject of this study. In this study, the situation of Polish and Ukrainian banking sector has also been analyzed from the point of view of the coefficient in question.

Yuanjuan \& Shishun (2012) have analyzed the prime crisis detonated fully exposed the risks of high leverage ratio of financial institutions operating, on the analysis of the effectiveness of capital adequacy is even more important. At that time, China's banking capital adequacy ratio is not entirely from external capital markets and bank performance improvement, and also the supervision of the superior pressure. The regression analysis on the 2005-2010 combined data of the 14 listed banks, China's listed banks' capital adequacy supervision must have the effect of has been shown. Continue to enhance the effectiveness of the capital adequacy ratio regulation.

Al-Tamimi and Obeidat (2013) have identified the most important factors that determine the capital adequacy of commercial banks of Jordan in Amman Stock Exchange for the period from 2000 - 2008 using Multiple Linear Regression Analysis and the Correlation Coefficient (Pearson Correlation). The study shows that there is a statistically significant positive correlation between the degree of capital adequacy in commercial banks and the following 
independent factors: liquidity risk, and the rate of return on assets. In another hand, there is an inverse relationship with statistical significance between the degree of capital adequacy of commercial banks and factors independent of the following: the rate of return on equity and interest rate risk. There is an inverse relationship is not statistically significant between the degree of capital adequacy in commercial banks and factors independent of the following: capital risk, credit risk, and the rate of force-revenue. As shown by the results of the study that the independent variables combined with a relatively high effect on the dependent variable and the changes that occur within, as the percentage of the interpretation of the independent variables of the dependent variable reached approximately 61 percent.

Abusharba, Triyuwono, Ismail, and Rahman (2013) have analyzed the determinants of the capital adequacy ratio in the Indonesian Islamic banking industry. Secondary data were obtained from Islamic banks annual reports and Islamic banking statistics that derived from Bank Indonesia covering the period of 2009 to 2011. Multiple linear regression analysis and pair-wise correlation matrix are used to explain the effect of explanatory variables; profitability (ROA), assets earning quality (NPF), deposits structure (DEP), liquidity (FDR) and operational efficiency (OEOI) on a proxy variable which is the capital adequacy ratio (CAR). The study found that profitability and liquidity are positively related to the capital adequacy requirements. Meanwhile, uncollectable funds measured by nonperforming financing (NPF) is significant but negatively related to the capital adequacy ratio. On the other hand, depositor's funds and operational efficiency have no significant effect on capital adequacy of Indonesian Islamic banks. Moreover, this study revealed that all selected Islamic commercial banks in Indonesia are committed over than 8 percent the minimum of capital requirements during the period of financial global crises. Finally, it was found that Indonesian Islamic banks have an excessive fund to meet their obligations and protect the owners of capital.

Bateni, Vakilifard and Asghari (2014) have focused on influential factors (precisely seven financial factors) over capital adequacy in Iranian private banks for the period 2006-2012. The results obtained indicate negative relationship between bank size and capital adequacy ratio of banks and positive relationship between Loan Asset Ratio (LAR), Return on Equity (ROE), and Return on Asset (ROA), Equity Ratio (EQR), and capital adequacy ratio. RAR and DAR do not have any impact on capital adequacy ratio.

Polat and Al-khalaf (2014) have presented an empirical evidence to explain some bank internal factors that influence the capital adequacy ratio (CAR) of listed banks in the Kingdom of Saudi Arabia (KSA). They have used the data covering from 2008 to 2012 for the Saudi Arabian Banks that are listed in Saudi Arabian Stock Market, Tadawul. By using a panel data and modelling through fixed effect, robust estimation and generalized least square (GLS) and feasible GLS, they found that except non-performing loans, other variables have significant effect on CAR. Depending on the model type the results vary. Fixed effect, robust estimation and least squared dummy regression (LSDR) results shows that loans to assets ratio has negatively significant while leverage and the size of the banks have positively significant in determining CAR. In GLS estimation they found that in addition to earlier model results, loan to deposit ratio has negatively significant and the return on assets has positively significant on 
CAR. The analysis of the study also shows that there are significant bank specific effects in panel data structure while no time effect is found.

Aktas, Acikalin, Bakin and Celik (2015) have evaluated the impact of bank-dimensional and environmental factors on bank's capital adequacy ratio in South Eastern European (SEE) region. Size, profitability (ROA), leverage, liquidity, net interest margin (NIM), and risk are used as bank-dimensional explanatory variables in a feasible GLS regression model. On the other hand, economic growth rate, inflation, real interest rate, Eurozone stock market volatility index, deposit insurance coverage, and governance indicator are added to the original model to control for environmental factors. Annual data from 71 commercial banks belong to 10 different countries in SEE region for the period of 2007 - 2012 is used. This region mainly consists of the "transition economies" which are still experiencing the difficulties of turning into efficient market economies with high economic potentials. The results of our study show that among the bank dimensional explanatory variables size, ROA, leverage, liquidity, net interest margin and risk have statistically significant effects in determining CAR for the banks in the region. Among the environmental factors, economic growth rate, Eurozone stock market volatility index, deposit insurance coverage, and governance have statistically significant effects in determining CAR for the banks in the SEE region.

Irawan, and Anggono (2015) have examined the determinants of capital adequacy ratio of Bank BUKU 3 and Bank BUKU 4 in Indonesia. Determinants and its effect toward capital adequacy ratio of Indonesian banks are covered by the study. Data were gathered from monthly financial statement of Indonesian banks during 2005-2014. Regression analysis was used in this study to analyze the relationships between independent variables; bank size (asset), deposits, credits, nonperforming loan, liquidity coverage ratio (LCR), profitability (ROA and ROE), and net interest margin (NIM) and a dependent variable which is capital adequacy ratio (CAR). The results of this study were assets, nonperforming loan, and ROA have positive effect toward the capital adequacy ratio, while ROE, NIM, credit, and deposit have negative effect toward the dependent variable. On the other hand, liquidity coverage ratio not has any significant effect toward the capital adequacy ratio.

Alajmi and Alqasem (2015) have identified the effects of seven internal factors of five conventional Kuwaiti banks on capital adequacy ratio (CAR). The five factors are: Loans to Assets, Loans to Deposits, Non- Performing Loans to Total Loans, Return on Assets, Return on Equity, Dividend Payout and Total Liability to Total Assets. The study covers the period from 2005 to 2013. The study shows that under fixed effect model, variables DIVIEDEND, LAR, LDR, NPLLR, and ROE do not have any impact on capital adequacy ratio. However, SIZE has a significant and negative relationship with capital adequacy ratio. Also, ROA shows a significant and negative relationship with capital adequacy ratio. Under random effect model, results indicate that CAR is adversely affected by bank's SIZE (total liability to assets), and ROA has a significant and negative relationship with capital adequacy ratio. However, Loan to Deposit Ratio (LDR) showed a significant and positive relationship with capital adequacy ratio. On the other hand, dividend payout, loans to assets, Non-Performing Loans to Total Loans and Return on equity do not have significant effect on CAR under random effect model. 
Asma and Khadidja (2015) have investigated the determinants of Malaysia Islamic banks capital adequacy ratio and its effects on financial positions of banks covered by the study. Data were obtained from banks' annual reports; other proxies were collected from bank scope database for the period 2006 - 2011. Capital adequacy ratio is the ratio which determines the bank's capacity to meet the time liabilities and other risks such as credit risk, operational risk etc. In the simplest formulation, a bank's capital is the "cushion" for potential losses, and protects the bank's depositors and other lenders. Banking regulators in most countries define and monitor CAR to protect depositors, thereby maintaining confidence in the banking system. Panel data methodology was used in this study and analyzes relationships between independent variables; bank size (SIZE), operational efficiency (OPR), liquidity risk (LQR), profitability (ROA and ROE), Credit risk (CR) and a dependent variable which was capital adequacy ratio (CAR). The results of the paper indicate that Credit risk (CR) and return on equity have a negative effect on CAR, while return on assets positively influence CAR. On the other hand operating efficiency (OPR), Liquidity risk (LR) and Bank size (SB) do not appear to have any significant effect on CAR.

El-Ansary \& Hafez (2015) have examined explanatory victors that influence capital adequacy ratio (CAR) in the Egyptian commercial banks. The study covers 36 banks during the period from 2004-2013. They have examined the relationship between CAR as dependent variable and the following independent variables: earning assets ratio, profitability, and liquidity, Loan loss provision as measure of credit risk, net interest margin growth, size, loans assets ratio and deposits assets ratio. Furthermore, they investigate determinants of CAR before and after the 2007- 2008 international financial crises. Results vary according to the period understudy. For the whole period 2003 to 2013 results show that liquidity, size and management quality are the most significant variables. Before the period 2008 results show that asset quality, size and profitability are the most significant variables. After the period 2009 results show that asset quality, size, liquidity, management quality and credit risk are the most significant variable that explain the variance of Egyptian banks' CAR.

Paudel and Khanal (2015) have explored that the capital adequacy ratio is a significant measure to evaluate efficiency and stability which affects the likelihood of insolvency for those institutions. Nepalese banks are applying Basel framework in order to maintaining a precise level capital standard. But, Nepalese cooperatives such as saving and credit cooperatives, multipurpose cooperatives, etc. are not regulated by the central bank, and thus, are not subjected to follow the Basel. In this regard, The study have evaluated the determinants of the capital adequacy ratio of Nepalese cooperative societies through descriptive, correlation, and regression analysis using an unbalance panel data of 126 co-operatives from 2009 to 2013. The core determinants of capital adequacy ratio for the Nepalese cooperatives are credit to deposit ratio, net interest margin and types of cooperative in positive direction, whereas assets utilization ratio, size and return on equity in negative direction. Though, the big sized cooperatives have poor strategic capital, the resulted mean and standard deviation suggest cooperatives' capital adequacy ratio is higher but inconsistent than commercial banks.

Mili, Sahut, Trimeche and Teulon (2016) have examined the factors influencing the capital adequacy ratio (CAR) of foreign banks. They have tested whether the CAR of subsidiaries and 
branches in developed and developing countries depends on the same factors. They have used data from 310 subsidiaries and 265 branches to test the impact of the parent banks' fundamentals on subsidiaries' and branches' capital ratios. They also study how the economic condition and regulatory environment in a bank's home country determine foreign banks' CAR. Our results provide strong evidence that the CAR of subsidiaries and branches operating in developing and developed countries do not depend on the same set of explanatory factors. They also find that the regulatory framework of a parent bank's home country affects the capitalization of its foreign subsidiaries in the host countries. The study show that specific variables of the parent bank have a stronger effect for foreign banks highly related to the interbank market.

Olarewaju and Akande (2016) have examined the determinants of capital adequacy in Nigerian quoted deposit money banks for the years 2005-2014. The study employs both descriptive and fixed effect panel regression. The descriptive analysis shows that the mean and median values are within the minimum values and the standard deviation shows the expected growth rate deviation for each of the identified determinants of capital adequacy. From the analysis of panel data using Cross-Sectional Specific fixed effect estimations, it is discovered that a direct relationship exists among ETA, ROA and SIZ while an inverse linear relationship that exists among ROA, CR, DEP and LIQ are statistically significant in determining the level of capital adequacy among the deposit money banks in Nigeria. The study recommends the need for all these affected banks to gear up and invest more on the significant factors that can lead to improvements in their capital adequacy in order to achieve viability, sustainability and stability in the long run.

Masood and Ansari (2016) have analyzed the bank specific factors which had an impact on the determination of Capital Adequacy Ratio (CAR). The impact of ROA (Return on Assets), ROE (Return on Equity), LAT (Loan to Asset ratio), LLR (Loan Loss Reserves), NPL (NonPerforming Loans), DAR (Deposit Asset Ratio), EAR (Equity Asset Ratio) and Ownership concentration with a level of more than $10 \%, 25 \%$ and $50 \%$ was analyzed by using Fixed Effect Method and the validity was tested by Hausman Test. The results proved that Random Effect Model is better suited in this case. The data of 14 Pakistani Commercial Banks which were included in the KSE (Karachi Stock Exchange) 100 Index was gathered for the period 20082014. The results revealed that the LAT and ownership concentration of more $50 \%$ had a significant but a negative impact on the CAR. The EAR, DAR, LLR had a significant and positive impact the determination of CAR, whereas the Size of the Bank, ROA, ROE and NPL had no impact on CAR.

Kasmadi, Lambey and Tumiwa (2017) have explained banks are expected to perform their activities effectively and efficiently in order to reach financial goals. A healthy standard for banks in Indonesia is determined by Central Bank (Bank Indonesia), which is above $8 \%$ for the indication of capital adequacy ratio. This research analyses the relationship between capital adequacy ratio and its determinants between Mandiri and Mandiri Syariah bank. This research examines the simultaneous and partial influences between capital adequacy ratio and the variables of return on equity, net interest margin, loan/financing to deposit ratio, and bank size by using time series regression and using the quarterly period of 2009-2016. The results reveal 
that the independent variables simultaneously affect capital adequacy ratio for both banks, and by partially, the results confirm that return on equity and bank size significantly affect capital adequacy ratio. With this research, companies are encouraged to figure out the root problems on how to manage a stable financial statement that may lay on some of the variables that are discussed in this study.

Thoa and Anh (2017) have analyzed the Vietnamese banks in the period 2011-2015 and shows how the Capital Adequacy Ratio (CAR) is influenced by selected factors, namely: asset of the bank SIZE, loans in total assets LOA, leverage LEV, net interest margin NIM, loans lost reserve LLR, Cash and Precious Metals in total assets LIQ. The result revealed that NIM and LIQ have significant effect on CAR. On the other hand, SIZE and LEV do not appear to have significant effect on CAR. Variables NIM, LIQ have positive effect on CAR, while variables LLR and LOA are negatively related with CAR.

Hewaidy and Alyousef (2018) have investigated the impact of bank-specific and macroeconomic factors on bank’s Capital Adequacy Ratio (CAR). Size, profitability (ROA \& ROE), Asset Quality (AQ), Management Quality (MQ), Liquidity (LIQ), Net Interest Margin (NIM), and bank type are used as bank-specific factors. Gross domestic product (GDP) and inflation are used as macroeconomic factors. Annual data for all Kuwaiti listed banks is used for the period from 2009 to 2016. The findings indicate that in terms of bank characteristics, only bank size, AQ, MQ and bank LIQ have significant impact on CAR. The findings suggests that CAR tends to be more affected by how efficient bank resources are utilized than by any other bank characteristic or macroeconomic variable.

Hadjixenophontos and Christodoulou-Volos (2018) have analyzed the determinants of capital adequacy of Cypriot banks mainly during the period of financial crisis using multiple linear regression. Specifically, the study focuses on certain features of banks (risk, liquidity, return etc.) to determine whether they affect the volatility of capital adequacy. The study provides supportive evidence that there is a negative statistically significant relationship regarding bank size and risk and a positive regarding the level of provisions and percentage of Net Interest Margin. The factors affecting the capital adequacy ratio in Cyprus are the increases in credit risk and nonperforming loans, excessive leverage, increased requirements by regulatory authorities for the implementation and fulfillment of the Basel III rules by 2019, the negative environment and lack of trust, intensive competition among banks, the small size of banks in comparison with the interbank market, low yield and target for long-term growth, poor corporate governance and the problem of information asymmetry. Moreover, in the case of Cyprus, the additional capital is a strategic hedge to secure access to deposits and money markets and "buffer" as insurance in case of unforeseen events in the future due to the previous negative experience.

AlAli (2019) has investigated the influence of capital adequacy on financial stability indexes in commercial banks in Jordan (Return on Invested Capital ROIC, profitability Rate PR), follows the descriptive analytic approach in order to analyze the results. The population of the study consists of all commercial banks in Jordan, A sample selected from these population (13) commercial banks in Jordan. The results of the study showed Most of Jordanian banks, 
committed to capital adequacy ratio defined in the international (Basel II), this ratio largest percentage of decided by the Base III Committee, and there is statistically significance influence of capital adequacy ratio on financial stability indexes (Profit Rate) and (return on invested capital ratio) in Jordanian banks.

Linh et al. (2019) have studied by using the data of 26 Vietnamese Join-stock Commercial banks. The result analysis through the Panel Tobit model, the research found that the Net interest margin (NIM), Bank size, GDP Growth, Interest rate and Exchange rate have the inverse relationship with CAR while the Leverage and Deposits positively correlated to CAR.

Usman, Lestari and Puspa (2019) have determined the factors that affect the CAR. The sample used in this study was the banking industry listed on the Indonesia Stock Exchange (IDX) from 2007 until 2018. Independent variables were bank size, leverage, loan loss reserves, net interest margin, loan assets ratio, and liquidity. The dependent variable was CAR. The number of samples is 27 conventional banks by using purposive sampling. By using panel data regression analysis by estimating ordinary General Least Squares (GLS) method. The results of this study indicate that bank size, leverage, loan loss reserve, net interest margin, and loan asset ratio has an effect on CAR significantly while liquidity has no effect on CAR. The results of this study are expected to be used as a reference for bank managers and investors in looking at the factors that affect the CAR in the banking industry.

\section{Research Methodology}

This study is based on the secondary balance panel data. The data were collected from the 11 commercial banks for the period of 2013/14 to 2017/18 leading to 55 observations. The annual report of respective commercial banks collected through the web site for banks specific variables and economic survey which is collected through the web page of Ministry of Finance were main source of data. The convenience sampling technique has been used to selection of sample of the study. The study period has been made for fresh data in the analysis. The descriptive, correlational and casual comparative research design has been used for data analysis. The selected banks for study are Nabil Bank, NIC Asia Bank, Machhapuchchhre Bank, Sanima Bank, Megha Bank, Everest Bank, Himalayan Banks, Nepal SBI Bank, Standard Chartered Bank, Prime Bank and Citizen Bank.

\subsection{The Model}

The study assumes that the capital adequacy ratio of commercial banks depends on bank specific variable: credit risk, asset quality, management quality, return on assets, liquidity, size of bank and macroeconomics variables gross domestic products growth rate and consumer price index i.e. inflation rate. Hence, the model takes the following form:

$\mathrm{CAR}_{\mathrm{it}}=\beta 0+\beta 1 \mathrm{CR}_{\mathrm{it}}+\beta 2 \mathrm{AQ}_{\mathrm{it}}+\beta 3 \mathrm{MQ}_{\mathrm{it}}+\beta 4 \mathrm{ROA}_{\mathrm{it}}+\beta 5 \mathrm{LIQ}_{\mathrm{it}}+\beta 6 \mathrm{SIZE}_{\mathrm{it}}+\beta 7 \mathrm{GDP}_{\mathrm{it}}+\beta$ $8 \mathrm{INF}_{\mathrm{it}}+\mathrm{e}_{\mathrm{it}}$

Where,

$\beta 0=$ Constant term 
$\beta 1$ to $\beta 8=$ Coefficient of Variables

$\mathrm{CAR}_{\mathrm{it}}=$ Capital Adequacy Ratio of $\mathrm{i}^{\text {th }}$ bank in year $\mathrm{t}$

$\mathrm{CR}_{\mathrm{it}}=$ Credit Risk Ratio of $\mathrm{i}^{\text {th }}$ bank in year $\mathrm{t}$

$A Q_{\text {it }}=$ Assets Quality of $i^{\text {th }}$ bank in year $t$

$\mathrm{MQ}_{\mathrm{it}}=$ Management Quality of $\mathrm{i}^{\text {th }}$ bank in year $\mathrm{t}$

ROAit $=$ Return on Assets of $i^{\text {th }}$ bank in year $t$

LIQ $i t=$ Liquidity of $\mathrm{i}^{\text {th }}$ bank in year $\mathrm{t}$

SIZEit $=$ Bank Size of $\mathrm{i}^{\text {th }}$ bank in year $\mathrm{t}$

GDP $=$ GDP Growth Rate in year $\mathrm{t}$

INF= Inflation Rate in year $\mathrm{t}$

$\mathrm{e}_{\mathrm{it}}=$ Error term

\subsection{Variables and Hypothesis}

The study has been selected capital adequacy as dependent variable. The study also have been taken bank specific variables: profitability, credit risk, management quality, liquidity, Size of bank, and asset quality and macroeconomics variable: gross domestic product growth rate and inflation rate as independent variables. The explanations about the measurement and hypothesis of the study have been described as follows.

\subsubsection{Dependent Variable}

\section{Capital Adequacy Ratio (CAR)}

Capital is important in banking and financial institutions. One of the essential requirements for banks and financial institutions is adequate and sufficient capital and every banks and financial organizations must keep balance between capital and available risk in its assets in order to guarantee its stability (Bateni et al.; 2014). Capital adequacy ratio is a measure of the amount of bank's capital measured as bank's capital expressed as a percentage of bank's total assets adjusted by loan loss provision and risk-free assets.

\subsubsection{Independent Variable}

\section{Bank Specific Variable}

\section{Credit Risk (CR)}

The non-performing loan to total loan ratio has proxy of credit risk in this study. The credit risk has positive and significant effects on capital adequacy ratio. The results of the studies related to the findings were Abusharba et al. (2013) and Hadjixenophontos and Christodoulou-Volos (2018). The result against to this line were Asma and Khadidja (2015), Mohanty and Mahakud (2019), and Usman, Lestari and Puspa (2019). This study has expected also negative relation with capital adequacy ratio. 
H1: Credit risk has negative significantly effect on capital adequacy ratio.

\section{Assets Quality (AQ)}

Asset quality refers to an evaluation of the credit risk associated with any particular asset, measured as loans loss provision to total assets. The study of El-Ansary and Hafez (2015) have found that assets quality have positive and significant with capital adequacy ratio. The studies have found negative and significant were: Blose (2001), Thoa and Anh (2017) and Usman, Lestari and Puspa (2019). In this study also expected negative relationship with capital adequacy ratio.

H2: Assets quality (loan loss provision on total asset ratio) has negative significantly effects on capital adequacy ratio.

\section{Management Quality (MQ)}

The total loans to total deposit as measured for management quality proxy. It has ability to generate business and maintain profit. The management quality have found positive and significant result with capital adequacy ratio. The study have been supported in the same line were: Aspal and Nazneen (2014), Aktas et al. (2015), Thoa and Anh (2017) and Alajmi and Alqasem (2015). The previous study of Polat and Al-khalaf (2014) has found that negative and statistically significant with capital adequacy ratio. Similarly, the study has expected positive relation with capital adequacy ratio.

H3: Management quality (ratio of total loan to total deposit) has positive significantly effect on capital adequacy ratio.

\section{Profitability (ROA)}

The net profit after tax to total assets has been measurement of return on asset (ROA). Which is also called profitability. The return on assets indicates the ability of bank management to generate profit by utilizing the available assets of bank. There is significant and positive result found between the profitability (ROA) and capital adequacy ratio. The previous studies have found in the same line were: Polat and Al-khalaf (2014), Asma and Khadidja (2015) and Adhikari (2017). In this study expected that there positive relationship with capital adequacy ratio.

H4: The profitability (ROA) has positive significantly effects on capital adequacy ratio.

\section{Liquidity (LIQ)}

Liquidity refers to the ability of a bank to respond to short-term obligations, measured as net loans to total assets. The priori studies have found positive and significant with capital adequacy ratio were: Abusharba, et al. (2013) and Bateni et al., (2014). The past studies liquidity has found negative and significant were: Buyuksalvarci and Adioglu (2011), Dreca (2013), Nuviyanti and Anggono (2014), Polat and Al-khalaf (2014), Thoa and Anh (2017), and Mohanty and Mahakud (2019). The study expected hypothesis is as follows.

H5: The Liquidity (loans asset ratio) has negative significantly effect on capital adequacy ratio. 


\section{Size of Bank (Size)}

The natural logarithm of total assets is measure to size of bank. There is significant and positive result found between the size of bank and capital adequacy ratio. The previous studies have found in the same line were: Polat and Al-khalaf (2014), Mekonnen (2015); El-Ansary and Hafez (2015), Mekonnen (2015), and Mohanty and Mahakud (2019). Similarly, the studies have found in against were: Al-Sabbagh (2004), Bateni et al., (2014), Alajmi and Alqasem (2015); Hewaidy and Alyousef (2018), Hadjixenophontos and Christodoulou-Volos (2018), Linh et al. (2019), and Usman, Lestari and Puspa (2019). Based on the priori studies capital adequacy has a negative influence with bank size, so that large banks have lower capital adequacy ratios, and more profitable banks have more capital adequacy high. Therefore, the present study has been formulated hypothesis as follows.

H6: The size of bank has negative significantly effect on capital adequacy ratio.

\section{Macroeconomic Variables}

\section{Gross Domestic Product Growth Rate (GDP)}

Gross Domestic Product growth rate (GDP) is a measure of economic growth. GDP is the annual rate of change in the total output of all economic activities of a country in Nepal. The GDP has found positive and statistically significant result s of Schaeck and Čihák (2007) and Mili et al. (2014), Aktas, et Al., (2015) and Ben Moussa (2018) in different countries. The GDP has found native and statistically negative in the study of Linh et al. (2019). In this regards, the present study has expected negative relationship with capital adequacy ratio.

H7: GDP has negative significantly effects on capital adequacy ratio.

\section{Inflation Rate (INF)}

Consumer price index, is a proxy for inflation rate which represents the macroeconomic conditions. The study of Schaeck and Čihák (2007), Ogere et al. (2013), Aktas, et Al., (2015) and Ben Moussa (2018) have found a positive association between inflation and capital adequacy ratio. The previous studied have found negative and significant relation with capital adequacy ratio were: Williams (2011), Ochei (2013) and Aktas, Acikalin, Bakin, and Celik (2015). The present study has also expected negative relationship with capital adequacy ratio.

H8: Inflation rate has negative significantly effects on capital adequacy ratio.

\subsection{Summary of Variables}

The selected study variable variables, measurements, nation, source and hypothesis (expected sign) have been presented in the Table1. 
Table 1. Summary of Variables, Measurements, Nation, Source of Findings and Expected Sign

\begin{tabular}{|c|c|c|c|c|}
\hline Variables & Measurement & Notation & Source of Findings & Exp.Sign \\
\hline Capital Adequacy Ratio & $\begin{array}{l}\text { Capital / Risk - Weighted } \\
\text { Assets } \\
\text { Or (Tier1 Capital +Tier } 2 \\
\text { Capital) to total Risk } \\
\text { Weighted Assets }\end{array}$ & CAR & $\begin{array}{l}\text { Buyuksalvarci and Adioglu (2011), Dreca (2013), } \\
\text { Nuviyanti and Anggono (2014), Polat and Al-khalaf } \\
\text { (2014), Thoa and Anh (2017), Mohanty and } \\
\text { Mahakud (2019), and Usman, Lestari and Puspa } \\
\text { (2019) }\end{array}$ & N/A \\
\hline Credit Risk & $\begin{array}{l}\text { Non-performing Loan to } \\
\text { Total Loan }\end{array}$ & $\mathrm{CR}$ & $\begin{array}{l}\text { (+) Abusharba et. al. (2013), } \\
\text { Hadjixenophontos and Christodoulou-Volos (2018) } \\
\text { (-) Asma and Khadidja (2015), Mohanty and Mahakud } \\
\text { (2019), Usman, Lestari and Puspa (2019) }\end{array}$ & - \\
\hline Assets Quality & $\begin{array}{l}\text { Loan Loss Provision to } \\
\text { Total Loan }\end{array}$ & $\mathrm{AQ}$ & $\begin{array}{l}\text { (+) El-Ansary and Hafez (2015) } \\
\text { (-) Blose (2001), Thoa and Anh (2017) and Usman, } \\
\text { Lestari and Puspa (2019) }\end{array}$ & - \\
\hline Management Quality & $\begin{array}{l}\text { Total Loan to Total } \\
\text { Deposit }\end{array}$ & MQ & $\begin{array}{l}\text { (+) Aspal and Nazneen (2014), Aktas et al. (2015), } \\
\text { Thoa and Anh (2017), and Alajmi and Alqasem } \\
\text { (2015) } \\
\text { (-) Polat and Al-khalaf (2014) }\end{array}$ & + \\
\hline Profitability & $\begin{array}{l}\text { Net profit after tax to } \\
\text { Total assets }\end{array}$ & ROA & $\begin{array}{l}\text { (+) Polat and Al-khalaf (2014), Asma and Khadidja } \\
\text { (2015)Adhikari (2017) }\end{array}$ & + \\
\hline Liquidity & Total Loan to Total Asset & LIQ & $\begin{array}{l}\text { (+) Abusharba, et al. (2013) and Bateni et al., (2014) } \\
\text { (-) Buyuksalvarci and Adioglu (2011), Dreca (2013), } \\
\text { Nuviyanti and Anggono (2014), Polat and Al-khalaf } \\
\text { (2014), Thoa and Anh (2017), and Mohanty and } \\
\text { Mahakud (2019) }\end{array}$ & - \\
\hline Size of Bank & $\begin{array}{l}\text { Natural Logarithm of } \\
\text { Total Assets }\end{array}$ & SIZE & $\begin{array}{l}\text { (+) Polat and Al-khalaf (2014), Mekonnen (2015); } \\
\text { El-Ansary and Hafez(2015), Mekonnen (2015), and } \\
\text { Mohanty and Mahakud (2019), } \\
\text { (-) Al-Sabbagh (2004), Bateni et al., (2014)., Alajmi } \\
\text { and Alqasem (2015); Hewaidy and Alyousef (2018), } \\
\text { Hadjixenophontos and Christodoulou-Volos (2018), } \\
\text { Linh et al. (2019), and Usman, Lestari and Puspa } \\
(2019)\end{array}$ & - \\
\hline Economic Growth & $\begin{array}{l}\text { Gross Domestic Products } \\
\text { Growth Rate }\end{array}$ & GDP & $\begin{array}{l}\text { (+) Schaeck and Čihák (2007) and Mili et al. (2014), } \\
\text { Aktas, et Al., (2015) and Ben Moussa (2018), } \\
\text { (-) Linh et al. (2019) }\end{array}$ & - \\
\hline Consumer Price Index & $\begin{array}{l}\text { Annual Average } \\
\text { consumer Price Index }\end{array}$ & INF & $\begin{array}{l}\text { (+) Schaeck and Čihák (2007), Ogere et al. (2013) } \\
\text { Aktas, et Al., (2015) and Ben Moussa (2018), } \\
\text { (-) Williams (2011), Ochei (2013) and Aktas, } \\
\text { Acikalin, Bakin, and Celik (2015) }\end{array}$ & - \\
\hline
\end{tabular}




\section{Results and Discussion}

\subsection{Descriptive Statistics}

Table 2 shows the summary statistics for study variables. The average capital adequacy ratio is 13.6percent. It shows that average capital adequacy ratio is beyond the limit of NRB. The maximum and minimum nonperforming loan ratio are 0.10 percent and 3.40 percent respectively. The standard deviation 0.833 percent which shows that low variation of credit risk. The average credit risk is 0.894 percent which less than 1 percent. It represented that Nepalese sample commercial banks has nonperforming loan less than percent.

Table 2. Summary Statistics, using the observations 1:1 - 11:5

\begin{tabular}{|c|c|c|c|c|}
\hline Variable & Min & Max & Mean & S.D. \\
\hline CAR & 10.6 & 23.0 & 13.6 & 2.36 \\
\hline CR(NPL/TL) & 0.0100 & 3.40 & 0.894 & 0.833 \\
\hline AQ(LLP/TL) & 0.00667 & 2.64 & 0.581 & 0.562 \\
\hline MQ(TL/TD) & 48.9 & 90.5 & 79.4 & 9.61 \\
\hline ROA & 0.970 & 2.89 & 1.81 & 0.398 \\
\hline LIQ(TL/TA) & 42.6 & 533. & 75.7 & 63.2 \\
\hline SIZE(LnTA) & 22.4 & 25.9 & 24.9 & 0.580 \\
\hline GDP & 0.400 & 7.40 & 4.60 & 2.51 \\
\hline INF & 4.48 & 9.90 & 7.32 & 1.98 \\
\hline
\end{tabular}

The average asset quality represent ratio the loan loss provision by total loan is 0.581 percent. It indicates that Nepalese commercial banks have provision on total loan have not big issues. The average return on assets is 1.81 percent. The total asset of commercial have return in average 1.81 percent. The minimum and maximum GDP growth rate are 0.40 percent and 7.40 percent. The minimum GDP growth rate was 2015/16 at that time Nepalese economy has suffered from earthquake. Due to the COVID -19 pandemic world economy will face the problem as earthquake. The average inflation rate is 7.32 percent. It shows that consumer price index has increased by 7.32 percent.

\subsection{Correlation Analysis}

The Pearson correlation coefficients of Study variables have been presented in Table 3. The capital adequacy ratio is dependent variable. The independent bank specific variable are credit risk, asset quality, management quality, return on assets liquidity and size of bank and macroeconomic variables are gross domestic products growth rate and inflation rate. 
Table 3. Pearson Correlation Coefficient of Study Variables

Correlation coefficients, using the observations 1:1 - 11:5

$(5 \%$ critical value $($ two-tailed $)=0.2656$ for $n=55$

\begin{tabular}{|c|c|c|c|c|c|c|c|c|c|}
\hline CAR & CR(NPL/TL) & $\mathrm{AQ}(\mathrm{LLP} / \mathrm{TL})$ & $\mathrm{MQ}(\mathrm{TL} / \mathrm{TD})$ & ROA & LIQ(TL/TA) & SIZE(LnTA) & GDP & INF & Variables \\
\hline \multirow[t]{9}{*}{1.0000} & -0.2577 & -0.2231 & -0.0857 & 0.1823 & 0.5351 & -0.0219 & 0.3315 & $\begin{array}{c}- \\
0.4398\end{array}$ & CAR \\
\hline & 1.0000 & 0.7124 & 0.0681 & $\begin{array}{c}- \\
0.0275\end{array}$ & -0.1055 & -0.2468 & 0.0302 & 0.1948 & CRNPLTL \\
\hline & & 1.0000 & -0.0075 & $\begin{array}{c}- \\
0.3192\end{array}$ & -0.1389 & -0.2941 & $\begin{array}{c}- \\
0.0360\end{array}$ & 0.2037 & AQLLPTL \\
\hline & & & 1.0000 & $\begin{array}{c}- \\
0.2893\end{array}$ & -0.0729 & -0.1751 & 0.0826 & $\begin{array}{c}- \\
0.1553\end{array}$ & MQTLTD \\
\hline & & & & 1.0000 & 0.2453 & 0.2779 & 0.0792 & $\begin{array}{c}- \\
0.0798\end{array}$ & ROA \\
\hline & & & & & 1.0000 & 0.0342 & 0.0906 & $\begin{array}{c}- \\
0.1157\end{array}$ & LIQTLTA \\
\hline & & & & & & 1.0000 & 0.0566 & $\begin{array}{c}- \\
0.3606\end{array}$ & LnTA \\
\hline & & & & & & & 1.0000 & $\begin{array}{c}- \\
0.7379\end{array}$ & GDP \\
\hline & & & & & & & & 1.0000 & INF \\
\hline
\end{tabular}

The Table 3 shows the relation of dependent and independent variables. The relation between capital adequacy ratio and credit risk, asset quality, management quality, size and inflation rate have negative. Whereas, the relation between capital adequacy ratio and profitability (return on assets), liquidity, and gross domestic products growth rate have positive.

\subsection{Regression Analysis}

As per model test diagnostics from Gretl statistical software for Pooled OLS or Fixed Effects Model suitable for this study has been done. Then, the result reveals that Joint significance of differing group means: $\mathrm{F}(10,36)=3.48343$ with p-value 0.00274725 The p-vale is $0.00274725<0.05$. The assumption of model selection is: A low p-value counts against the null hypothesis that the Pooled OLS model is adequate, in favor of the fixed effects alternative. Hence, the as p-value less than 0.05, the Fixed Effect Model is appropriate for this case.

Again, the model test for the Pooled OLS or Random Effect Model appropriate for this study has been test. Then, the result shows that Breusch-Pagan test statistic: LM $=3.50017$ with pvalue $=\operatorname{prob}($ chi-square $(1)>3.50017)=0.0613625$. The p-vale 0.0613625 is greater than 0.05 . The assumption of hypothesis test is: A low p-value counts against the null hypothesis that the pooled OLS model is adequate, in favor of the random effects alternative. Hence, the P-value is greater than 0.05 , the Pooled OLS is suitable in this case. 
Table 4. Regression Results of Determinants of Capital Adequacy Ratio

\begin{tabular}{|c|c|c|c|c|c|}
\hline \multicolumn{6}{|c|}{ Model 1: Pooled OLS, Using 55 Observations } \\
\hline Variables & Coefficient & Std. Error & t-ratio & $p$-value & VIF \\
\hline Constant & 52.9958 & 14.4722 & 3.662 & $0.0006 * * *$ & \\
\hline CR(NPL/TL) & -0.451491 & 0.452642 & -0.9975 & 0.3238 & 2.486 \\
\hline $\mathrm{AQ}(\mathrm{LLP} / \mathrm{TL})$ & -0.0467778 & 0.693644 & -0.06744 & 0.9465 & 2.655 \\
\hline MQ(TL/TD) & -0.0386466 & 0.0280702 & -1.377 & 0.1752 & 1.272 \\
\hline ROA & 0.432214 & 0.744346 & 0.5807 & 0.5643 & 1.533 \\
\hline LIQ(TL/TA) & 0.0165215 & 0.00395380 & 4.179 & $0.0001 * * *$ & 1.094 \\
\hline SIZE(LnTA) & -1.31335 & 0.508406 & -2.583 & $0.0130 * *$ & 1.524 \\
\hline GDP & -0.0837411 & 0.156297 & -0.5358 & 0.5947 & 2.683 \\
\hline INF & -0.662252 & 0.218182 & -3.035 & $0.0039 * * *$ & 3.274 \\
\hline \multicolumn{2}{|c|}{ R-squared $=0.528917$} & & \multicolumn{2}{|c|}{ Adjusted R-squared $=0.446989$} & \\
\hline \multicolumn{2}{|c|}{$\begin{array}{l}\text { Test for Different Group Intercepts : } \\
\text { Test statistic: } F(10,36)=3.48343\end{array}$} & & \multicolumn{2}{|c|}{$\begin{array}{l}\mathrm{p} \text {-value }=\mathrm{P}(\mathrm{F}(10,36)>3.48343)= \\
0.00274725<0.05\end{array}$} & \\
\hline \multicolumn{2}{|c|}{ Durbin-Watson $=1.099494$} & & & & \\
\hline \multicolumn{6}{|c|}{ Model 2: Fixed Effects, Using 55 Observations } \\
\hline & Coefficient & Std. Error & t-ratio & $p$-value & \\
\hline Constant & 20.5851 & 14.9288 & 1.379 & 0.1764 & \\
\hline CR(NPL/TL) & -0.510662 & 0.730723 & -0.6988 & 0.4891 & \\
\hline AQ(LLP/TL) & 0.696559 & 0.870140 & 0.8005 & 0.4287 & \\
\hline MQ(TL/TD) & 0.0853605 & 0.0525413 & 1.625 & 0.1130 & \\
\hline ROA & -0.296984 & 0.974650 & -0.3047 & 0.7623 & \\
\hline LIQ(TL/TA) & 0.0128240 & 0.00360295 & 3.559 & $0.0011 * * *$ & \\
\hline SIZE(LnTA) & -0.440132 & 0.550544 & -0.7995 & 0.4293 & \\
\hline GDP & 0.0146814 & 0.139311 & 0.1054 & 0.9167 & \\
\hline INF & -0.448347 & 0.194758 & -2.302 & $0.0272^{* *}$ & \\
\hline \multicolumn{2}{|c|}{ LSDV R-squared $=0.760582$} & & \multicolumn{2}{|c|}{ Within R-squared $=0.581996$} & \\
\hline LSDV F(18, 36 & 6.353594 & & P-value $(F)=$ & $0134<0.05$ & \\
\hline \multicolumn{2}{|c|}{ Durbin-Watson $=1.462053$} & & & & \\
\hline \multicolumn{6}{|c|}{ Model 3: Random Effects (GLS), Using 55 Observations } \\
\hline & Coefficient & Std. Error & $Z$ & $p$-value & \\
\hline Constant & 47.6715 & 14.4045 & 3.309 & $0.0009 * * *$ & \\
\hline CR(NPL/TL) & -0.508522 & 0.465715 & -1.092 & 0.2749 & \\
\hline $\mathrm{AQ}(\mathrm{LLP} / \mathrm{TL})$ & 0.0789790 & 0.707937 & 0.1116 & 0.9112 & \\
\hline MQ(TL/TD) & -0.0306310 & 0.0286947 & -1.067 & 0.2858 & \\
\hline ROA & 0.454224 & 0.740372 & 0.6135 & 0.5395 & \\
\hline LIQ(TL/TA) & 0.0160952 & 0.00383045 & 4.202 & $<0.0001^{* * *}$ & \\
\hline SIZE(LnTA) & -1.14188 & 0.507847 & -2.248 & $0.0245^{* *}$ & \\
\hline GDP & -0.0631796 & 0.151005 & -0.4184 & 0.6757 & \\
\hline INF & -0.622759 & 0.211413 & -2.946 & $0.0032^{* * *}$ & \\
\hline \multicolumn{2}{|c|}{ Breusch-Pagan Test : } & & \multicolumn{2}{|c|}{ Hausman Test : } & \\
\hline \multicolumn{2}{|c|}{$\begin{array}{l}\text { Asymptotic test statistic: } \\
\text { Chi-square(1) }=3.50017\end{array}$} & & \multicolumn{2}{|c|}{$\begin{array}{l}\text { Asymptotic test statistic: } \\
\text { Chi-square(6) }=34.272\end{array}$} & \\
\hline \multicolumn{2}{|c|}{$\mathrm{p}$-value $=0.0613625>0.05$} & & \multicolumn{2}{|c|}{$\mathrm{p}$-value $=0.00000596<0.05$} & \\
\hline \multicolumn{2}{|c|}{ Durbin-Watson = 2.080926} & & & & \\
\hline
\end{tabular}

Similarly, the selection process has been done for model test between Random Effect and Fixed Effect model. The result of Hausman test statistic: $\mathrm{H}=34.272$ with $\mathrm{p}$-value $=$ prob(chi- 
square $(6)>34.272)=0.00000596$ The assumption of hypothesis test is: A low p-value counts against the null hypothesis that the random effects model is consistent, in favor of the fixed effects model. The p-vale is lower than 0.05 shows that among tested models the Fixed Effects Model is appropriate in this case.

Thus, the study has been explained Pooled OLS and Random Effects model in this study as model diagnostics tested.

The Table 4 presented the analysis of regression results among credit risk, assets quality, management quality, profitability, liquidity, size of bank, growth rate of gross domestic products and inflation rate towards the capital adequacy ratio on different three like Pooled OLS, Fixed Effects Model, and Random Effects Model.

The liquidity has positive and statistically significant effects on capital adequacy ratio. It shows that liquidity and capital adequacy have moving toward the same direction. The results consistent with the study of Abusharba, et al. (2013) and Bateni et al., (2014). The results of the study contrary with the study of Buyuksalvarci and Adioglu (2011), Dreca (2013), Nuviyanti and Anggono (2014), Polat and Al-khalaf (2014), Thoa and Anh (2017), and Mohanty and Mahakud (2019). The results of the study has as per priori hypothesis.

Size of bank has negatively and statistically significant result. It shows that large bank have low capital adequacy ratio. The result supported by priori studies were: Al-Sabbagh (2004), Bateni et al., (2014), Alajmi and Alqasem (2015); Hewaidy and Alyousef (2018), Hadjixenophontos and Christodoulou-Volos (2018), Linh et al. (2019), and Usman, Lestari and Puspa (2019). The result of the study has inconsistent with the previous studies were: Polat and Al-khalaf (2014), Mekonnen (2015); El-Ansary and Hafez (2015), Mekonnen (2015), and Mohanty and Mahakud (2019).

Inflation rate has negatively associated with capital adequacy ratio. The result has as per priori hypothesis. When inflation rate has decreases the capital adequacy ratio increases. It shows the inflation rate effect on the capital adequacy ratio adversely. The study result in the similar line were: Williams (2011), Ochei (2013) and Aktas, Acikalin, Bakin, and Celik (2015). The study results inconsistent with the studies were: Schaeck and Čihák (2007), Ogere et al. (2013) Aktas, et Al., (2015) and Ben Moussa (2018).

The profitability and asset quality have positive but insignificant with capital adequacy ratio. They have positive effect on capital adequacy but statistically insignificant. The credit risk, management quality and growth of gross domestic products have negative and insignificant with capital adequacy ratio. It shows that profitability, asset quality, credit risk, management quality and growth of gross domestic products does not have role to determine capital adequacy ratio.

\section{Summary and Conclusion}

The study attempts to determining the capital adequacy ratio of commercial banks in Nepal. This study is based on the secondary balance panel data. The data were collected from the 11 commercial banks for the period of 2013/14 to 2017/18 leading to 55 observations. The 
convenience sampling technique has been used to selection of sample of the study. The study period has been made for fresh data in the analysis. The descriptive, correlational and casual comparative research design has been used for data analysis. The study assumes that the capital adequacy ratio of commercial banks depends on bank specific variable: credit risk, asset quality, management quality, return on assets, liquidity, size of bank and macroeconomics variables gross domestic products growth rate and consumer price index i.e. inflation rate. The three different model like Pooled OLS, Fixed Effects Model and Random Effects Model have been used for data analysis. The results of the study revealed that the liquidity has positive and statistically significant effects on capital adequacy ratio. Size of bank and inflation rate have negatively and statistically significant results. The others variables profitability, asset quality, credit risk, management quality and growth of gross domestic products does not affect capital adequacy ratio. The study concluded that liquidity, size of bank and inflation have major determinants of capital adequacy ratio in Nepal.

\section{References}

Abba, G.O, Okwa, E, Soje, B., Aikpitanyi, L.N. (2018). Determinants of capital adequacy ratio of Deposit Money Banks in Nigeria. J Account Mark, 7, 271. https://doi.org/10.4172/21689601.1000271

Abusharba, M.T., Triyuwono, I., Ismail, M. \& Rahman, A.F. (2013). Determinants of capital adequacy ratio (CAR) in Indonesian Islamic commercial banks. Global Review of Accounting and Finance, 4(1), 159 - 170.

Aktas,R., Acikalin, S., Bakin, B. Celik, G. (2015).The determinants of banks' capital adequacy ratio: Some evidence from South Eastern European Countries. Journal of Economics and Behavioral Studies, 7(1), 79-88. https://doi.org/10.22610/jebs.v7i1(J).565

Alajmi, M., \& Alqasem, K. (2015). Determinants of capital adequacy ratio in Kuwaiti bank. Journal of Governance and Regulation, 4(2), 315-322.

IAli, S.M. (2019). Influence of capital adequacy on financial stability indexes a field study in commercial banks in Jordan. Academy of Accounting and Financial Studies Journal, 23(4), 110.

Al-Tamimi, K. A. Md. \& Obeidat, S. F. (2013). Determinants of capital adequacy in commercial banks of Jordan an empirical study. International Journal of Academic Research in Economics and Management Sciences, 2(4), 44-58. https://doi.org/10.6007/IJAREMS/v2$\mathrm{i} 4 / 53$

Asma, T. \& Khadidja, K. (2015). Determinants of capital adequacy ratio in Malaysia Islamic banks (A Panel Data Analysis). International Research Journal of Finance and Economics, 129, 55-63.

Bateni,L., Vakilifard, H., \& Asghari, F. (2014). The influential factors on capital adequacy ratio in Iranian banks. International Journal of Economics and Finance, 6(11), 108-116. https://doi.org/10.5539/ijef.v6n11p108 
Białas, M. \& Solek, A. (2010). Evolution of capital adequacy ratio. Economics \& Sociology, 3(2), 48-57. https://doi.org/10.14254/2071-789X.2010/3-2/5

El-Ansary, O. A., \& Hafez, H. M. (2015). Determinants of capital adequacy ratio: An empirical study on Egyptian banks. Corporate Ownership \& Control, 13(1), 806-815. https://doi.org/10.22495/cocv13i1c10p4

Hadjixenophontos, A. \& Christodoulou-Volos, C. (2018). Financial crisis and capital adequacy ratio: A case study for Cypriot commercial banks. Journal of Applied Finance \& Banking, 8(3), 87-109.

Hewaidy, A. M. \& Alyousef, H.Y. (2018). Bank-specific and macroeconomic determinants of capital adequacy ratio: Evidence from Kuwaiti banks. European Journal of Economics, Finance and Administrative Sciences, 99, 5-20.

Irawan, K. \& Anggono, A.H. (2015). A study of capital adequacy ratio and its determinants in Indonesian banks: A panel data analysis. International Journal of Management and Applied Science, 1(9), 98-101.

Kasmadi, K.A., Lambey, L. \& Tumiwa, J.R. (2017). Analysis of factors affecting capital adequacy ratio between Islamic bank and Conventional bank case study - Mandiri Syariah and Mandiri (2009-2016). Jurnal EMB, 5(3), 3794-3803

Linh, D.H., Phuong, N.T.H., Xuan, N.T., Duc, L.A., Diep, N.T.N. \& Trang, N.H. (2019). Determinants of capital adequacy ratio of Vietnamese commercial banks. International Journal of Business, Economics and Law, 18(5), 300-310.

Masood, U. \& Ansari, S. (2016). Determinants of capital adequacy ratio: A perspective from Pakistani banking sector. International Journal of Economics, Commerce and Management, IV(7), 247-273.

Mili, M., Sahut, J-M., Trimeche, H., \& Teulon, F. (2016). Determinants of the capital adequacy ratio of foreign banks' subsidiaries: The role of interbank market and regulation. Research in International Business and Finance. https://doi.org/10.1016/j.ribaf.2016.02.002

Mohanty, S., \& Mahakud, J. (2019). Dynamic adjustment towards target capital adequacy ratio: Evidence from Indian commercial banks. Global Business Review, 20(3), 757-768. https://doi.org/10.1177/0972150919837082

Nuviyanti \& Anggono, A. H. (2014). Determinants of capital adequacy ratio (CAR) in 19 commercial banks (Case study: Period 2008 - 2013). Journal of Business and Management, 3(7), 752-765.

Olarewaju, O.M. \& Akande, J.O. (2016). An empirical analysis of capital adequacy determinants in Nigerian banking sector. International Journal of Economics and Finance, 8(12), 132-142. https://doi.org/10.5539/ijef.v8n12p132

Paudel, G.P. \& Khanal, S. (2015). Determinants of capital adequacy ratio (CAR) in Nepalese cooperative societies. https://doi.org/10.2139/ssrn.2647541 


\section{Macrothink}

Asian Journal of Finance \& Accounting

ISSN 1946-052X 2020, Vol. 12, No. 1

Polat, A. and Al-khalaf, H. (2014). What determines capital adequacy in the banking system of Kingdom of Saudi Arabia? A panel data analysis on Tadawul Banks. Journal of Applied Finance \& Banking, 4(5), 27-43.

Shrieves, R. E., \& Dahl, D. (1992). The relationship between risk and capital in commercial banks. Journal of Banking \& Finance, 16(2), 439-457. https://doi.org/10.1016/03784266(92)90024-T

Thoa, P.T.X. \& Anh, N.N. (2017). The determinants of capital adequacy ratio: The case of the Vietnamese banking system in the period 2011-2015. VNU Journal of Science: Economics and Business, 33(2), 49-58. https://doi.org/10.25073/2588-1108/vnueab.4070

Usman, B., Lestari, H.S., \& Puspa, T. (2019). Determinants of capital adequacy ratio on banking industry: Evidence in Indonesia Stock Exchange. Jurnal Keuangan dan Perbankan, 23(3), 443- 453. https://doi.org/10.26905/jkdp.v23i3.2981

Yuanjuan, L. \& Shishun, X. (2012). Effectiveness of China's commercial banks' capital adequacy ratio regulation: A case study of the listed banks. Interdisciplinary Journal of Contemporary Research in Business, 4(1), 58-68. 